UCRL-ID-135931

\title{
History and Status of the CIS Customs Union
}

T.M. Lawson, S.A. Erickson

August 31, 1999

U.S. Department of Energy

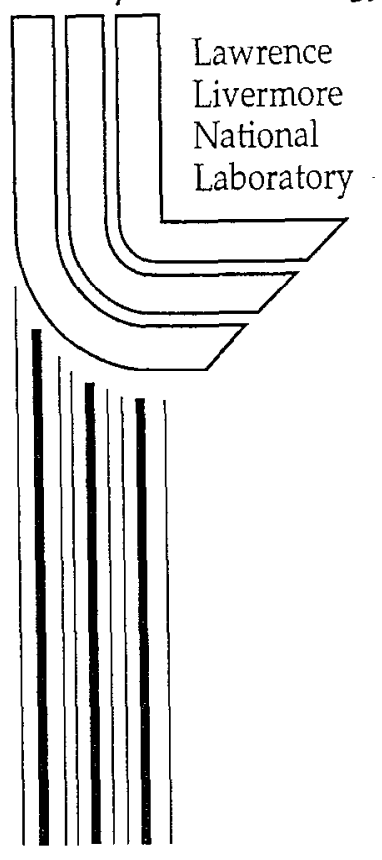




\section{DISCLAIMER}

This document was prepared as an account of work sponsored by an agency of the United States Government. Neither the United States Government nor the University of California nor any of their employees, makes any warranty, express or implied, or assumes any legal liability or responsibility for the accuracy, completeness, or usefulness of any information, apparatus, product, or process disclosed, or represents that its use would not infringe privately owned rights. Reference herein to any specific commercial product, process, or service by trade name, trademark, manufacturer, or otherwise, does not necessarily constitute or imply its endorsement, recommendation, or favoring by the United States Government or the University of California. The views and opinions of authors expressed herein do not necessarily state or reflect those of the United States Government or the University of California, and shall not be used for advertising or product endorsement purposes.

This report has been reproduced directly from the best available copy.

Available to DOE and DOE contractors from the Office of Scientific and Technical Information

P.O. Box 62, Oak Ridge, TN 37831

Prices available from (615) 576-8401, FTS 626-8401

Available to the public from the

National Technical Information Service

U.S. Department of Commerce

5285 Port Royal Rd.,

Springfield, VA 22161 


\section{History and Status of the CIS Customs Union}

Tiffany M. Lawson, Lawrence Livermore National Laboratory

PO Box 808; L-175 Livermore, CA 94551

Telephone: 925/422-2996 FAX: 925/422-9292<lawson18@1ln1.gov>

Stanley A. Erickson, Lawrence Livermore National Laboratory

PO Box 808; L-181 Livermore, CA 94551

Telephone: 925/422-6548 FAX: 925/422-8471<serickson@llnl.gov>

\section{Abstract:}

This report explores the history of the CIS Customs Union and the major obstacles the Union faces in its implementation. Investigation of the Customs Union is necessary as its implementation could effect the Second Line of Defense(SLD) Program. Russian Customs contends that radiation detectors should not be installed along the Customs Union members borders of as the borders will be dissolved when the Union is implemented.

\section{HISTORY}

The history of the Commonwealth of Independent States (CIS) Customs Union dates back to the dissolution of the former Soviet Union in 1991. Following the break-up, trade fell between CIS member states dramatically. From 1991 to 1992, Belarus' trade with Russia fell $44 \%$ in exports and $39 \%$ in imports. Ukraine's trade with Latvia fell $60-70 \%$ by $1995 .{ }^{1}$ The decline in trade over the entire area exceeded 50\% between 1991 and $1996 .^{2}$ There is a general belief among the CIS leaders that it was the severing of these trade ties which was responsible for the catastrophic recession that they have experienced. ${ }^{3}$ At a Minsk CIS summit in January 1993, Russian President Boris Yeltsin declared, "... we have realized that we cannot live without each other."4

In September of 1993, the Treaty on Economic Union sought to create a "phased common economic space based on market relations." Despite this treaty, it was not until April of 1994 that a concrete step toward a customs union was taken when Belarus and Russia signed an agrecment sceking to unify their economies. In April, 1995 the customs posts on the border between Russia and Belarus were dismantled and in July, 1995, all customs controls over trade between Russia and Belarus stopped.

In January 1995, Kazakhstan was admitted into the Customs Union and in January, 1996, Yeltsin lifted customs controls on the Russia-Kazak border. In September, 1995 Kyrgyzstan, Tajikistan,

\footnotetext{
'Recker, Abraham S. "Russia and Economic Integration in the CIS." Survival, v38, pg, 120.

${ }^{2}$ Michalopoulos, Constantine and Tarr, David. "The Economics of Customs Union in the Commonwealth of Independent States." Post-Soviet Geography and Economics, v38, n3, pg. 125.

${ }^{3}$ Becker, Abraham S. "Russia and Economic Integration in the CIS." Survival, v38, pg. 120.

${ }^{4}$ Ibid.

${ }^{5}$ Ibid.
} 
and Uzbekistan declared their intentions to join the customs union and in March, 1996 Kyrgyzstan was admitted.

In April, 1996 Russia and Belarus formalized their previous agreement to join together as a "union state" in a redundant agreement The Economist referred to as, "... if not quite the silliest document to have been signed between European countries in modern times, it must rank as one of the most cynical." " As part of this agreement, a common external tariff was agreed on (again), however the members resolved to "modify" it as they saw fit.

In January, 1998, Russia, Belarus, Kazakhstan, and Kyrgyzstan signed an agreement to form a common tariff structure despite the fact that tariff structures were already set by several of the previous agreements. Finally, in February, 1999, Tajikistan was admitted to the Customs Union.

\section{STATUS}

In Stage One of Customs Union creation, a common customs territory was to be set up along with an administrative body. This stage's goal is to abolish internal borders and apply common-or preferably no-tariffs. This stage has been in the process of implementation since the inception of the CIS Customs Union. The Customs Union will not be considered "operational" until full implementation of free trade is complete and a full set of procedures for regulating foreign trade is followed.

Stage Two would create a common economic policy, encourage nations to develop and share a common infrastructure (market of goods, labor, services, and capital) and create a transport union. This stage would also involve the creation of a common monetary unit, the ability to allow citizens to travel and live freely within the Customs Union, the creation of a valid system of trade payments, and the synchronization of monetary and fiscal policies to control exchange rates.

Currently, the CIS Customs Union treaty stipulates that member governments agree to the coordination of customs rules and economic activity, assure mutual convertibility of national currencies at the official exchange rate, support mutual efforts at protecting the external borders, and regulate the tariffs producing a fully free trade zone. In reality, very few of these regulations are followed with any consistency or clarity. Currently, tariffs are not standardized, there is no agreement on Value Added Tax (VAT) levels, and there is no standard customs declaration procedure.

\section{PROBLEMS ENCOUNTERED}

Many nations are forced to breech CIS Customs Union accords to compete and survive. From 1965 to 1990, the tariff rate within the Soviet Union changed only once. Since 1990, it has changed nearly every quarter. ${ }^{7}$ Due to an inability to compete with other Customs Union members, in February, 1999, Kazakhstan imposed a 21-category restriction on Russian

\footnotetext{
6 "Alexander the Not So Great." The Economist, 13 April 1996,pg. 42.

${ }^{7}$ Koshkaryova, Tatyana. "Import Tariffs Pit Producers Against Consumers." Current Digest of the Post Soviet Press, March 20 , 1994, pg. 8."
} 
foodstuffs and a $200 \%$ import duty on goods from Kyrgyzstan. ${ }^{8}$ However, according to the Customs Union charter that Kazakhstan signed, all members must trade without duties. This was not the first time Kazakhstan imposed technically illegal tariffs upon CIS Customs Union members but it is not the only member do so.

Economic necessity caused Russia-arguably the leader of the Union-to resort to unethical trade practices such as the 1998 trade war with Belarus over the dumping of trucks on the Belarusian market. In 1994, Russia imposed a $100 \%$ tariff on tanks and a 50\% tariff on aircraft. ${ }^{9}$ Wildly fluctuating tariffs, VATs, and customs duties are common among all CIS Customs Union nations with the exception of Kyrgyzstan, who has a $10 \%$ uniform tariff due to its conformity with World Trade Organization (WTO) regulations. However, according to CIS Customs Union regulations, $10 \%$ is still a violation. This highlights another problem-the Union has no means of enforcing its regulations.

Another important problem is that of fair competition. Differing degrees of technical know-how, enthusiasm, and productive capacity among member nations creates an environment in which free trade cannot occur on a level playing field. Consequently, some states will always be forced to impose taxes and tariffs, thus undermining the very purpose of the Customs Union.

The problem of balance of payments with the Union will continue to stall implementation. Without a reliable system of payment, trade among the member states is very difficult. Russia is currently owed billions of dollars in back payments from CIS nations. Yeltsin acknowledged the gravity of the payment problem when he said, "The problem of settlements is a serious one. Normal trade will simply be impossible unless that problem is resolved. It is disappointing that it is not yet clear how to create an effective mechanism for payments..."10

Russia is continuously faced with economically supporting the other CIS nations in what is known as the "Burden of Empire." Russian subsidies to the CIS nations ranged between \$17-67 billion from 1992 to $1996 .{ }^{11}$ But the burden is not a problem for Russia alone. Dependency on Russia makes the members vulnerable to Russian economic pressure and runs the risk of subjecting them to Russia's economic problems as well their own.

An additional problem is that of the "special relations" between Russia and Belarus which are viewed as a threat to Union equality. Uzbek President Islam Karimov told reporters at the Moscow Customs Union Summit, "The creation of unions of two, four, or five countries is intentionally or unintentionally hurting the CIS because those who remain on the sidelines are invited to discuss only what has already been agreed upon... There is only one way to integration-a free trade zone." 12 n additional consideration is the resulting differing levels of integration. Belarus and Russia are far more integrated than other members. Also, the fact that Russia is the dominant member of the Customs Union has not gone unnoticed by the other

\footnotetext{
${ }^{8}$ Novoprudskiy, Semen. "Feasibility of Customs Union Accords Questioned." Izvestiya, 27 February 1999.

${ }^{9}$ Koshkaryova, Tatyana. "Import Tariffs Pit Producers Against Consumers." Current Digest of the Post Soviet Press, March 20, 1994, pg. 8 .

${ }^{10}$ Becker, Abraham S. "Russia and Economic Integration in the CIS." Survival, $\vee 38$, pg. 122.

"Becker, Abraham S. "Russia and Economic Integration in the CIS." Survival, v38, pg. 130.

12 "Uzbek President Criticizes CIS Customs Union Summit." Moscow Interfax, 2 March 1999.
} 
members. Russia can push other nations to do as Russia wishes. For example, Belarus is largely dependent on Russian oil and gas despite the fact that Belarus has several refineries of its own. ${ }^{13}$

Agreements within the Customs Union are abundant. Several of the many agreements recently presented are, "On Migration," "Ten Steps for the Ordinary Man," "On State Secrets," and "On Fundamentals of the Foreign Economic Activity." It is estimated that economic integration of the CIS Customs Union will require an additional 50 agreements. ${ }^{14}$ The sheer number of agreements makes ratification and implementation practically impossible, particularly in light of the fact that ratifying these agreements would require surrendering some level of national sovereignty by new nations who are weary of Russian domination. "Their common attitude may be surmised as regret for the economic damage caused by thoughtlessly severing economic ties, but little appetite for restoring the old regime." 15

Since Kazakhstan and Russia have shown interest in WTO membership (Kyrgyzstan was admitted on 20 December, 1998), arguments among the CIS Customs Union members have escalated. WTO trade regulations and obligations differ tremendously from those of the CIS Customs Union and many nations fear that when the interested parties join the WTO, they will no longer be interested in their CIS Customs Union membership. Belarusian President Aleksander Lukashenka said at a recent meeting that Kyrgyzstan's admission to the WTO will "invariably lead to conflict"16 and Kazakhstan has "already virtually left the Customs Union." 17

\section{EFFECTS ON SLD}

Open borders between Russia and many states engaged in the drug trade has allowed drugs to flow more freely into Russia. The price of a gram of heroin in Moscow fell from $\$ 200$ to $\$ 50-80$ in three years. ${ }^{18}$ Law enforcement agencies confiscated the largest cache of heroin in Russian history this year when they found 220 kilograms in a fake gas tank of a truck. What most surprised them was the relative ease in which a smuggler could travel from Afghanistan (an area rich in heroin), through Tajikistan, and into Russia. In 1998, 80\% of all heroin found in Russia came through Kazakhstan or Tajikistan from Afghanistan. ${ }^{19}$

Due to the admittance of Tajikistan and Kazakhstan into the CIS Customs Union, smuggling drugs across the border has become relatively simple-so simple that heroin has become the most common drug in Russia, with confiscation's of it growing last year by a factor of five. ${ }^{20}$ Tajikistan is considered a member of the "golden crescent," a group of heroin-rich countries which also includes Pakistan and Afghanistan.

\footnotetext{
${ }^{13}$ Humphreys, Jennifer. "Hope for a Union." International Business: Strategies for the Global Marketplace, March 1997.

${ }^{14}$ Semiryaga, Vladimir. "The 'Group of Five' Have Decided to live Properly, Time Will Tell How Far They Succeed." Krasnaya Zvezda, 6 March 1999."

${ }^{15}$ Becker, Abraham S. "Russia and Economic Integration in the CIS." Survival, v38, pg. 122.

${ }^{16}$ Michalopoulos, Constantine and Tarr, David. "The Economics of Customs Union in the Commonwealth of Independent States." Post-Soviet Geography and Economics, v38, n3, pg. 138.

${ }^{17}$ Borov, Sergey. "Lukashenka's Sensational Statement, Members Clarify Positions Ahead of Meeting Customs Union Heads." Nezavisimaya Gazeta, 26 February 1999.

${ }^{18}$ Feofilaktova, Anna and Grishin, Alexei. "Heroin Corridor into Russia." Moscow News, 11 February 1999.

${ }^{19}$ Ibid.

${ }^{20}$ Ibid.
} 
While no direct evidence concludes that the CIS Customs Union would allow freer transport of smuggled radiolngical material, the fact that it is easier than ever to transport drugs suggest a similar situation could exist for radiological materials.

\section{RECCOMENDATION}

My recommendation is to approach the other CIS Customs Union members about providing detection equipment and training on their respective borders. Russia may have over estimated its ability to implement a customs union and is now in a position in which abandoning it would be politically embarrassing. WTO membership could eliminate the necessity of the Customs Union however, it may take years for the other Union members to be admitted to the WTO so waiting for this to happen and then approaching Russia again could waste valuable time.

\section{CONCLUSION}

In relation to radiological smuggling and the CIS Customs Union, it may be a blessing that the Union is so dysfunctional. Although it may allow occasional openings on the borders, rampant abuses of tariffs raises the likelihood that transports are commonly inspected due to sheer greed.

The Union appears to do little for its members to provide a free trade area or encourage a revival of the trade that occurred prior to 1991. Without major changes, the CIS Customs Union may be doomed to be little more than a series of superfluous agreements.

\section{ACKNOWLEDGEMENT}

This work was preformed under the auspices of the U.S. Department of Energy by Lawrence Livermore National Laboratory under contract No. W-7405-Eng-48. 


\section{APPENDIX}

C.IS Customs Union Timeline

September 1993 The Treaty on Economic Union is written calling for a "phased creation of a common economic space based on market relations."

January $1994 \quad$ Russia and Belarus declare their intention to unify their economies.

April $1994 \quad$ The Russia-Belarus agreement is signed

January $1995 \quad$ Kazakhstan is admitted to the customs union.

April 1995 Customs posts on the border between Russia and Belarus are dismantled.

July 1995 All customs controls on trade between Russia and Belarus are removed.

September 1995 Kyrgyzstan, Tajikistan, and Uzbckistan declare thcir intentions to join the Customs Union.

January 1996 Yeltsin decrees the lifting of custom controls on the Russia-Kazak border.

March 1996 Kyrgyzstan is admitted to the Customs Union.

Treaty on the Deepening of Integration in the Economic and Humanitarian Spheres presented.

April 1996 Russian and Belarus formalize their agreement to join together in a "union state."

January 1998 Russia, Belarus, Kazakhstan, and Kyrgyzstan sign an agreement to form a common tariff structure.

February 1999 Tajikistan is admitted to the customs union. 